Collection: NFZ Summer School 2009 - Birmensdorf (Switzerland)

Long-term ecosystem research: understanding the present to shape the future Guest Editor: Marcus Schaub (WSL, Switzerland)

\section{Monitoring the effects of air pollution on forest condition in Europe: is crown defoliation an adequate indicator?}

\begin{abstract}
Johnson $\mathrm{J}^{(1)}$, Jacob $\mathrm{M}^{(2)}$
Forest condition in Europe is monitored under the International Co-operative Program on Assessment and Monitoring of Air Pollution Effects on Forests (ICP Forests). The focus of the program is to provide an overview of the status of forest ecosystems in Europe with respect to air pollution and contribute to the understanding of the relationship between pollution and forest health. Crown condition parameters, i.e., defoliation and discoloration, are used as the principal indicators of forest condition within the ICP Forest network. Crown condition assessments have been successful in disproving the "forest die-back" hypothesis. However, there are a number of limitations associated with this approach given the current monitoring objectives. Data from crown condition assessments indicate that stand age and country differences explain most of the variation in crown defoliation. It is difficult to clearly discern the effects of air pollution from other site and stress factors. The results do however indicate the role of meteorology and other factors. A better understanding of the relationships between forest condition and air pollution may be achieved if more specific, quantitative response variables are selected. However, we suggest that the original focus of the program on air pollution effects may need to be re-evaluated.
\end{abstract}

Keywords: Air pollution, Forest health, Monitoring, Crown condition, Defoliation

\section{Introduction}

Forest condition in Europe has been monitored for over twenty years under the International Co-operative Program on Assessment and Monitoring of Air Pollution Effects on Forests (ICP Forests), operating under the UNECE Convention on Long-range Transboundary Air Pollution (CLRTAP). The aims of the program are "to provide a

(1) Environmental and Life Sciences Program, 1600 West Bank Drive, K9J 7B8 Peterborough, Ontario (Canada); (2) Department of Plant Ecology, Albrecht von Haller Institute of Plant Sciences, GeorgAugust-Universität Göttingen, Untere Karspüle 2, D-37073 Göttingen (Germany)

@) Mascha Jacob (mjacob@gwdg.de)

Received: May 25, 2010 - Accepted: May 31, 2010

Citation: Johnson J, Jacob M, 2010. Monitoring the effects of air pollution on forest condition in Europe: is crown defoliation an adequate indicator? iForest 3 : 86-88 [online: 2010-07-15] URL:

http://www.sisef.it/iforest/show.php? id $=538$ periodic overview on the spatial and temporal variation of forest condition in relation to anthropogenic and natural stress factors (in particular air pollution)" and to gain a better understanding of the cause-effect relationships between the condition of forest ecosystems and these factors (De Vries et al. 2003). One of the key aspects of a successful monitoring design is the selection of a suitable indicator. It is necessary that the indicator(s) chosen be measurable, have low natural variability, be appropriate to the scale of disturbance and be indicative of a potential cause (Wiersma 2004). Since its inception, crown condition parameters (defoliation and discoloration) have been used as the main indicators of forest health within the ICP Forests program. Monitoring of crown condition takes place at two different intensity levels: a systematic large-scale monitoring network (Level 1) and an intensive monitoring program (Level II). The use of crown defoliation and discoloration as indicators has been subject to much criticism and a number of limitations have been highlighted with this approach (Innes 1993, Ferretti \& Chiarucci 2003). In this paper, we de- scribe the background to the current monitoring program and discuss the results of crown condition surveys as well as the adequacy of using crown condition as an indicator of air pollution.

\section{Monitoring the effects of air pollution on forest condition in Europe}

At the time when the concern for air pollution peaked in the mid 1980 s, some researchers claimed that the forest of Europe would die over large areas and within a few years (e.g., Ulrich \& Matzner 1983, Wentzel 1982). The public media and partly the politicians adopted this view and there was a need for a rapid response (Schäfer \& Metzger 2009). Crown defoliation and discoloration assessments provided a quick method of assessing whether forest die back was occurring across a wide area. However, at that time, a number of researchers disagreed with the mainstream thinking, i.e., they did not expect a severe decline to take place (Rehfuess 1990, Kandler 1994, Ellenberg 1995, Ellenberg 1996, Hüttl 1998). If their view had been adopted at that time, another monitoring approach with more air-pollution specific and sensitive indicators might have been developed.

Monitoring of forest condition over the years has been successful in disproving the "forest die-back" hypothesis. Little evidence has been found for a widespread effect of air pollution on tree health in European forests (Ulrich 1995). Instead, climate conditions seem to have a major effect on crown condition and tree growth (Kandler \& Innes 1995, Solberg \& Torseth 1997). Foliar injury and mortality is found to occur in specific areas, e.g., Czech Republic and Eastern Germany, and may be attributed to high concentrations of sulphur dioxide in combination with other stresses (e.g., climate and insects - Kandler \& Innes 1995).

Today, monitoring of crown condition to assess the effects of air pollution on forests continues under the ICP Forests programs at approximately 6000 plots in the Level I network and more than 800 Level II plots (Fischer et al. 2007). The aim of the Level II network is to determine whether a number of proposed cause-effect relationships between air pollution and forest condition are occurring. These relationships include on the one hand the direct effects of air pollutants, such as sulphur dioxide $\left(\mathrm{SO}_{2}\right)$, nitrogen oxides $\left(\mathrm{NO}_{\mathrm{x}}\right)$ and tropospheric ozone $\left(\mathrm{O}_{3}\right)$, on leaf stomata, and on the other hand the indirect effects on forest condition, i.e., soil acidification due to sulphur (S) and soil eutrophication by nitrogen $(\mathrm{N})$ deposition. At selected intensive sites, a number of parameters including soil solution and chemistry as well 
as foliar chemistry are sampled to provide an indication of the "chemical" forest condition, which in turn may influence crown condition (De Vries et al. 2003).

\section{Limitations of crown condition as an indicator of forest condition}

The adequacy of the current monitoring design in achieving its aims has been subject to questions (Ferretti \& Chiarucci 2003). In particular, a number of limitations associated with crown condition parameters have been highlighted (Ferretti \& Chiarucci 2003 , Innes 1993). Crown defoliation and discoloration are not specific to any direct or indirect influence of air pollutants. Instead, they integrate the effects of natural factors such as site conditions (e.g., soil), intrinsic factors (e.g., age, phenology), biotic stress (pests, fungi), and meteorological conditions, as well as air pollutants (Innes 1992, De Vries et al. 2000). In addition, several relevant stress factors, which may affect defoliation are currently not included in the current monitoring program, these include forest management practices (e.g., thinning), mechanical hazards due to meteorological events (e.g., storm damage) as well as biotic stress (e.g., diseases and competition - Klap et al. 2000). Crown condition is also influenced by the history of the site and development processes, which are often unknown or unquantifiable (Aber \& Driscoll 1997, Hüttl et al. 2009).

Crown condition assessments are also subject to a high degree of uncertainty due to the subjective nature of the observation involved (Ferretti 1998). Klap et al. (2000) and Seidling (2001) found that as much as $30 \%$ of the variability in defoliation between countries can be attributed to methodological differences. Statistical techniques were used to account for this "country-effect" but it is likely that the significance of stress factors is limited by this effect (Klap et al. 2000).

Finally, the results of the monitoring program should be useful for the validation and development of protocols on the impacts of air pollution (De Vries et al. 2003). While statistical evaluations may find a significant relationship between air pollution and crown defoliation, they have not contributed to the development of critical loads of atmospheric deposition.

\section{General results from crown condition assessments at Level I and Level II sites}

These limitations are evident in the results of correlative studies, which attempt to explain the variation in crown defoliation regarding site conditions (e.g., soil chemistry, altitude) and other stress factors such as deposition of $\mathrm{S}$ and $\mathrm{N}$, air pollution $\left(\mathrm{SO}_{\mathrm{x}}, \mathrm{NO}_{\mathrm{x}}\right.$, $\mathrm{O}_{3}$ ) as well as meteorology (e.g., De Vries et al. 2000, Klap et al. 2000, Lorenz et al. 2003,
Seidling 2001). Country differences and stand age account for the largest variation in crown condition (Klap et al. 2000, Seidling 2001). As a result of this and due to the limitations outlined above, it is difficult to clearly discern the effects of air pollution (e.g., $\mathrm{O}_{3}, \mathrm{SO}_{2}, \mathrm{~N}$ and $\mathrm{S}$ deposition) on forest ecosystems. For example, some studies have reported a significant negative correlation between $\mathrm{SO}_{4}^{2-}$ and crown defoliation of Pinus sylvestris based on Level I data (Klap et al. 2000, Fischer et al. 2002), other studies using Level I and Level II data have not found any correlations (De Vries et al. 2000, Seidling 2001). In addition, where a significant relationship with defoliation is found, the contribution of air pollution is often small (e.g., Klap et al. 2000).

The relationship between crown condition and nitrogen deposition is also not clear. De Vries et al. (2000) reported that nitrogen deposition was positively correlated with defoliation in oak (Quercus robur) and beech (Fagus sylvatica), but it was negatively correlated with defoliation in spruce (Picea abies). In contrast, nitrogen was not found to be significant on the same species by Seidling (2001) or Klap et al. (2000). Fischer et al. $(2002,2003)$ found that for some species, e.g., $P$. abies and F. sylvatica, ammonium deposition was correlated with deterioration in crown condition, while nitrate coincided with an improvement. These results could reflect either a eutrophying or an acidification effect.

\section{Conclusion}

There is large potential within the ICP Forest's monitoring network to collect and evaluate data that can contribute to environmental policy. The strength of the network lies in the extensive number of sites and the length of time series for which data have been recorded. Crown condition assessments have successfully shown that the "forest dieback" hypothesis was unfounded. However, it is clear from the results of correlative studies that crown condition assessments do not provide a clear overview of the variation in forest condition nor improve our understanding of cause-effect relationships between forest condition and air pollution. A better understanding of the relationships between forest condition and air pollution may be achieved if more specific, quantitative response variables are selected. This is particularly relevant with respect to specific air pollution threats such as ozone. However, it may also be argued that the original objectives of the program may need to be reevaluated. The mandate of the program was, and still is, specific with respect to the effects of atmospheric pollution on forest ecosystems; yet the relationships found are generally weak and often geographically limited. We argue that the focus of the pro- gram on air pollution effects should be redirected to take into account current threats to forest health in Europe.

\section{Acknowledgements}

We would like to thank the organizers of the NFZ Summer School for giving us the opportunity to publish this short paper, in particular Dr. Marcus Schaub, Dr. Michèle Kaennel Dobbertin and Dr. Matthias Dobbertin. We would also like to acknowledge the valuable comments and assistance provided by Dr. Svein Solberg, Dr. Markus Neuman and two anonymous reviewers. James Johnson would also like to acknowledge the provision of Research Stimulus Funding from Department of Agriculture, Fisheries and Food (Ireland). The provided funding of the German Research Foundation for the "Graduiertenkolleg 1086" (http:// www.forest-diversity.uni-goettingen.de/) is greatly acknowledged by Dr. Mascha Jacob.

\section{References}

Aber JD, Driscoll CT (1997). Effects of land use, climate variation, and $\mathrm{N}$ deposition on $\mathrm{N}$ cycling and $\mathrm{C}$ storage in northern hardwood forests. Global Biogeochemical Cycles 11: 639-648. doi: 10.1029/97GB01366

De Vries W, Reinds GJ, van Kerkvoorden M, Hendriks CMA, Leeters EEJM, Gross C, Voogd J, Vel E (2000). Intensive monitoring of forest ecosystems in Europe. Technical Report 2000, UNECE/EC, Geneva, Brussels, Belgium.

De Vries W, Vel E, Reinds GJ, Deelstra H, Klap JM, Leeters EEJM, Hendriks CMA, Kerkvoorden M, Landmann G, Herkendell J, Haussmann T, Erisman JW (2003). Intensive monitoring of forest ecosystems in Europe. 1. Objectives, set-up and evaluation strategy. Forest Ecology and Management 174: 77-95. - doi: 10.1016/S0378-1127(02)00029-4

Ellenberg H (1995). Neuartige Waldschäden? Ökologische Kritik an den Untersuchungsmethoden. Allgemeine Forstzeitschrift 796-797.

Ellenberg H (1996). Vegetation Mitteleuropas mit den Alpen: In ökologischer, dynamischer und historischer Sicht. Ulmer, Stuttgart, Germany.

Ferretti M (1998). Potential and limitations of visual indices of tree condition. Chemosphere 36: 1031-1036. - doi: 10.1016/S0045-6535 (97)10167-9

Ferretti M, Chiarucci A (2003). Design concepts adopted in long-term forest monitoring programs in Europe - problems for the future? The Science of the Total Environment 310: 171-178. - doi: 10.1016/S0048-9697(02)00637-X

Fischer R, De Vries W, Barros M., Van Dobben H., Dobbertin M., Gregor HD, Larsson TB, Lorenz M, Mues V, Nagel HD, Neville P, Sanchez-Pena G, De Zwart D (2002). The condition of forests in Europe, 2002 executive report. UN/ECE, Geneva, Brussels, Belgium.

Fischer R, De Vries W, Beuker E, Calatayud V, Fürst A, Häberle K-H, Haußmann T, Karnosky DF, Krause GHM, Gundersen P, Lorenz M, 
Luyssaert S, Matyssek R, Mayer F-J, Meining S, Mues V, Neville P, Percy KE, Posch M, Preuhsler T, Raitio H, Reinds GJ, Renaud JP, Sanz MJ, Schulze ED, Vel E (2003). Forest condition in Europe, executive report. UNECE/EC, Geneva, Brussels.

Fischer R, Mues V, Becher G, Lorenz M. (2007). Monitoring of atmospheric deposition in European forests and an overview on its implication on forest condition. Applied Geochemistry 22: 1129-1139. - doi: 10.1016/j.apgeochem.2007. 03.004

Hüttl R (1998). Neuartige Waldschäden. In: Berlin-Brandenburgische Akademie der Wissenschaften, vol. 5, pp. 131-215.

Hüttl RFJ, Schneider U, Bend O (2009). Longterm ecosystem research: why monitoring is so important. In: "Long-term ecosystem research: understanding the present to shape the future" (Kaennel Dobbertin M ed). Zurich (Switzerland), 7-11 Sept 2009.

Innes JL (1992). Forest decline. Progress in Physical Geography 16: 1-64. - doi: 10.1177/ 030913339201600101

Innes JL (1993). Forest health: its assessment and status. Commonwealth Agricultural Bureau, Wallingford, CT, USA.
Kandler O (1994). Vierzehn Jahre Waldschadensdiskussion - Szenarien und Fakten. Naturwissenschaftliche Rundschau 11: 419-430.

Kandler O, Innes JL (1995). Air pollution and forest decline in central Europe. Environmental Pollution 90: 171-180 - doi: 10.1016/02697491(95)00006-D

Klap J, Oude Voshaar J, De Vries W, Erisman J (2000). Effects of environmental stress on forest crown condition in Europe. Part IV. Statistical analysis of relationships. Water Air and Soil Pollution 119: 387-420. - doi: 10.1023/ A:1005157208701

Lorenz M, Mues V, Becher G, Fischer R, Luyssaert S, Raitio H, Fürst A, Langouche D (2003). Forest condition in Europe. 2003 Technical Report. UNECE/EC, Geneva, Brussels, Belgium.

Rehfuess KE (1990). Übersicht über den Stand der Waldschadensforschung unter besonderer Berücksichtigung bodenkundlicher Forschungsansätze. In: Die Entwicklung der Waldschäden (Weiß J-P ed). Wilhelm-Münker-Stiftung, Siegen, 30: 36-60.

Schäfer R, Metzger B (2009). Was macht eigentlich das Waldsterben? In: "Umweltgeschichte und Umweltzukunft - Zur gesellschaftlichen Relevanz einer jungen Disziplin" (Masius P, Sparen- berg O, Sprenger J eds). Graduiertenkolleg Interdisziplinäre Umweltgeschichte, Universitätsverlag Göttingen, Germany.

Seidling W (2001). Integrative studies on forest ecosystem conditions. Multivariate evaluations on tree crown condition for two areas with distinct deposition gradients. UNECE/EC, Geneva, Brussels.

Solberg S, Tørseth K (1997). Crown condition of Norway spruce in relation to sulphur and nitrogen deposition and soil properties in southeast Norway. Environmental Pollution 96: 19-27 doi: 10.1016/S0269-7491(97)00010-9 .

Ulrich B, Matzner E (1983). Ökosystemare Wirkungsketten beim Wald- und Baumsterben. Forst- und Holzwirt 38: 468-474.

Ulrich B (1995). The history and possible causes of forest decline in central Europe, with particular attention to the German situation. Environmental Reviews 3: 262-276. [online] URL: http://pubs.nrc-cnrc.gc.ca/cgi-bin/rp/ rp2 abst f?/er a95-013 3 ns nf er3-4-95

Wentzel KF (1982). Ursachen des Waldsterbens in Mitteleuropa. Allgemeine Forstzeitschrift 45: 1365-1368.

Wiersma GB (2004). Environmental monitoring. CRC Press, Boca Raton, FL, USA. 